\title{
Challenges for Chimeric Antigen Receptor T Cell Therapies in the Clinical Setting: Mechanisms of Resistance in Non-Responders
}

\author{
Priya Hays* \\ Talis Biomedical Corporation, Menlo Park, USA \\ *Corresponding author: Priya Hays, Talis Biomedical Corporation, Menlo Park, USA
}

\begin{tabular}{|c|c|}
\hline ARTICLE INFO & ABSTRACT \\
\hline Received: 㓞 February 19, 2020 & Citation: Priya Hays. Challenges for Chimeric Antigen Receptor T Cell Therapies in the \\
\hline Published: 幽 February 26, 2020 & $\begin{array}{l}\text { Clinical Setting: Mechanisms of Resistance in Non-Responders. Biomed J Sci \& Tech Res } \\
\text { 26(1)-2020. BJSTR. MS.ID.004285. }\end{array}$ \\
\hline
\end{tabular}

\section{Opinion}

Chimeric antigen receptor $\mathrm{T}$ cell therapy, also known as CAR T cell therapy, has been shown to have significant clinical efficacy for B-cell malignancies by genetically engineering autologous cells to attack cancer cells when infused into patients [1]. However recently, using an ingeniously developed CRISPR-Cas9 loss of function technique performed on acute lymphoblastic cells, investigators have interrogated clinical samples and revealed a correlation between death receptor gene expression, including FADD and BID, in pre-treatment samples and response after CART19 [2]. They have identified that impairments in leukemia and lymphoma death receptor signaling lead to primary CART19 resistance, which in turn mediate progressive CAR T cell functional impairment, revealing a novel mechanism of resistance against CAR $\mathrm{T}$ cell therapy. The authors also performed transcriptomic and epigenomic profiles on these cells and uncovered clustered gene expression profiles and areas of chromatin accessibility using ATAC-Seq between responsive and unresponsive cells [2]. Additionally, the study found that death receptor expression correlated with clinical outcomes in patients after treatment with tisagenlecleucel, also known as Kymriah.

This study is extremely critical considering the increasing number of clinical trials with CAR T cell therapies on hematological patients that are taking place, and that the Food and Drug Administration (FDA) is approving CART at breakthrough pace based on urgent need. It raises a series of concerns on how to best utilize CART to effectively treat relapsed and refractory malignancies if there exist a sizable number of non-responders. Currently, companion diagnostics to detect markers, genetic or otherwise, for determining responders for targeted immunotherapy treatment are not considered robust enough, and as CART is still ongoing, the development of companion diagnostics has not proven viable yet. Furthermore, the implications for treatment of solid tumors will come under further scrutiny as a result of this study investigating B-cell malignancies. This study might suggest the use of epigenetic or transcriptomic biomarkers for differentiating responders or non-responders of CART therapy, perhaps necessitating the use of deep sequencing or arrays in clinical settings and thus complicating the treatment of these therapies. In short, that while CART has proven to be a profound treatment for cancer patients, with higher remission and lower side effects, the elucidation of this mechanism of resistance might undercut the future treatment of cancer patients.

\section{Conflict of Interest}

Dr. Priya Hays has no conflicts of interests to disclose.

Dr. Priya Hays is an employee of Talis Biomedical Corporation (Talis). The views expressed in this paper are her own and do not necessarily represent those of Talis, its parents, subsidiaries, or related Talis entities.

\section{References}

1. Hays P (2019) Review of therapeutic approaches for B-cell malignancies with immune checkpoint blockade and chimeric antigen receptor T-cell therapies: development, benefits and limitations. J Clin Invest Stud 2: $1-6$

2. Singh, N, Lee, YG, Shestova, O, Ravikumar P, Hayer KE, et al. (2020) Impaired death receptor signaling in leukemia causes antigenindependent resistance by inducing CAR $\mathrm{T}$ cell dysfunction. Cancer Discovery. 


\section{ISSN: 2574-1241}

DOI: 10.26717/BJSTR.2020.26.004285

Priya Hays. Biomed J Sci \& Tech Res

\section{(c) (P) This work is licensed under Creative}

Submission Link: https://biomedres.us/submit-manuscript.php

$\begin{array}{ll}\text { BIOMEDICAL } & \text { Assets of Publishing with us } \\ \text { RESEARCHES } & \text { Global archiving of articles } \\ & \text { - Immediate, unrestricted online access } \\ & \text { - Rigorous Peer Review Process } \\ \end{array}$

